\title{
A zase ten učitel?
}

\section{Petr Urbánek}

\section{Letošní první číslo Pedagogiky přináší čtyři klíčové statě.} $S$ výjimkou jediné mají všechny př́íspěvky značně hutný rozsah. Ten by ovšem čtenáře neměl nikterak odrazovat, nebot' texty jsou zajímavé a čtivé a zabývají se významnými, aktuálními a také nově uchopenými tématy. Přitažlivost čísla zvyšuje i různorodost typů publikovaných textů; zastoupena je teoretická, přehledová i výzkumná studie.

V pořadí první statí je publikační výsledek výzkumného projektu, na kterém spolupracovali odborníci z brněnské a pražské pedagogické fakulty. Tomáš Janík, Radka Wildová, Klára Uličná, Eva Minaříková, Miroslav Janík, Jana Jašková a Barbora Šimůnková se v ní zabývají u nás stále do jisté míry přehlíženou problematikou adaptačního období začínajícího učitele. Autoři na základě vybraných zahraničních modelů navrhují i pro české prostředí tolik chybějící systémové řešení podpory učitele $\mathrm{v}$ této jeho klíčové etapě profesní dráhy. Odborná analýza a diskuse $\mathrm{k}$ tématu začínajícího učitele a jeho profesní podpory je vysoce aktuální a užitečná, zvláště v době určitého "procitnutí“ a zvýšeného zájmu decize o učitele a jeho profesi, a také v souvislosti se stále vyššími nároky, které jsou na učitele kladeny.

Druhý časopisecký příspěvek Jiř́ho Mareše př̌ináší nový pohled na dosud nesledovanou rovinu profesní zátěže učitele, a to v oblasti profesně morálních dilemat, kterým je učitel často a trvale vystavován a které mají přirozeně své důsledky. Fenomén popisovaného morálního distresu učitelů nemusí být vždy zcela zjevný a autor jej proto označuje jako „skrytý problém“. Dodejme, že rizikem je jeho kumulativní účinek a na učitele má selektivní dopad. Text, tak jak bývá u autora dobrým zvykem, je přehledný, čtivý a př́nosný v tom, že otevírá doposud neodhalovanou rovinu zkoumání profesní zátěže a přináší celou řadu 
inspirativních podnětů. Autor na př́kladu zahraničních výzkumů fenoménu morálního distresu, kterému jsou vystaveni zdravotníci, nachází paralelu s učitelskou profesí. Výzvou pro pedagogickou výzkumnou komunitu jsou autorem zmíněné zahraniční dotazníkové nástroje ke zjištování morálního distresu ve výzkumech zdravotnického personálu, které by bylo zcela jistě užitečné modifikovat i pro výzkum tohoto fenoménu v českém školském prostředí.

V pořadí třetí časopisecký text je také inspirován zahraničím a situací v mnoha ohledech nikoli nepodobnou českým poměrům. Př́ípadová studie sleduje oblast skotského školního kurikula a zkušenosti s jeho implementací do školní výuky. Cenné jsou autory odhalované kontexty a analogie k české situaci kurikulární reformy. Také toto téma, byt’ nepř́mo, mírí $\mathrm{k}$ práci učitelů, $\mathrm{k}$ jejich postojům ke kurikulu, $\mathrm{k}$ výukovým možnostem a nárokům, ale též $\mathrm{k}$ míře jistoty, se kterou mohou učitelé $\mathrm{v}$ oblasti vzdělávacích obsahů pracovat. Velmi potěšitelný je signál, který autorská dvojice tohoto textu implicitně vysílá. Zkušený badatel a významný odborník tematiky kurikula, Dominik Dvořák, vtahuje touto publikační spoluprací doktoranda Jakuba Holce do bezesporu stále naléhavé a dynamické oblasti výzkumu.

Čtveřici textů uzavírá od těch předchozích tematicky poněkud odlišný článek Jana Hábla. Ve stati orientované k filozofii výchovy se autor kultivovanou dikcí vrací ke Komenskému. Klade zde klíčovou otázku vychovatelství a učitelství, kdo je člověk, se všemi konsekvencemi pro výchovu a lidskou přirozenost. Aniž by o to autor záměrně usiloval, podařilo se mu zarámovat své komeniologické zamyšlení nad časopiseckým číslem jako celkem, když vztahuje principy ukotvenosti, stability a řádu, spirituality, dobra a zla či osobní identifikace až do edukativních poloh. Činí tedy to, co v utilitárních a unáhleně hektických konceptech složitého dneška mnohdy chybí: vycházet z výchovné podstaty a odkrývat pravý smysl veškerého výchovného snažení.

Přestože se první letošní číslo časopisu Pedagogika na první pohled jeví svým tematickým zaměřením jako různorodé, při bližším prostudování končí všechna témata prríspěvků nakonec u učitele. A zřejmě je to prríznačné i odůvodněné. Vždyt jen učitel je a také bude tím konečným realizátorem at už dobrých, lepších či špatných idejí, konceptů nebo obsahů. Právě jen on může ještě leccos nepodařeného zachránit, anebo také něco zdařilého $v$ realitě vlastní výuky pokazit. Zaleží ale v prvé řadě na něm, na jeho profesních kvalitách, na profesním přesvědčení a bezesporu též na podpoře, které se mu dostává. Nejde proto o nikterak nový nebo objevný, spíše stále jen nevyslyšený apel, požadujeme-li v zájmu kvalitní školy učinit především něco pro učitele. $V$ oblasti jeho vzdělávání, $\mathrm{v}$ podpoře podmínek učitelské práce, $\mathrm{v}$ akceptaci profesní autonomie učitele, v reálně stanovených požadavcích a adekvátních očekáváních. Vždy ale v souladu s logikou profesního přesvědčení učitelů a nikoli v rozporu s ní, v souladu s učitelem, nikoli proti němu. Jiří Mareš ve své stati výstižně ilustruje fenomén morálního distresu učitelů na př́kladu implementace kurikulární reformy před deseti lety do našich škol. 
Jde o precedens, kdy právě nebyly brány ohledy na reálné možnosti a na profesní přesvědčení učitelů. Autor poukazuje na zdroj morálního distresu, se kterým byli učitelé konfrontováni $\mathrm{v}$ důsledku konfliktu mezi shora diktovaným kurikulárním konceptem a jejich vlastním profesním přesvědčením. Učitelé nebyli o smysluplnosti konceptu ani o užitečnosti předkládaných změn přesvědčeni. Tyto žádané změny proto povětšinou přijali jen váhavě a s nedůvěrou, anebo je nepřijali vůbec. Jedno celé uplynulé desetiletí ilustruje kontraproduktivnost důsledků nedomyšlených koncepčních zásahů vzdělávací politiky, které se neopíraly o učitele. Nicméně, dodnes jsou z rozpačitých výsledků reformy některými autory obviňováni učitelé, jejich rigidita a neochota ke změnám.

Uvedený př́klad ovšem není již př́liš aktuální, aby bylo možné jeho nepř́íznivý výsledek zvrátit či získat zpět ztracenou důvěru učitelstva při prríštích decizních intervencích. Nabídnu proto ještě jiný, naléhavější příklad hrozícího morálního distresu, u kterého bude muset mnohý učitel opět „zradit sám sebe a připustit, že se bude podílet na něčem, s čím nesouhlasil“. Neukazuje se totiž vủbec, že realizaci konceptu inkluzivního vzdělávání $\mathrm{v}$ jeho nevyjasněnosti a nepřipravenosti učitelé pozitivně přijímají. A mezi jiným má již tradici, že se samotných učitelů na jejich postoj, tj. na názor konečných realizátorů, opět nikdo neptal. Nebyla akceptována ani opakovaná kritická stanoviska či analýzy odborných profesních asociací k projektu společného vzdělávání. Potenciální neřešitelnost $\mathrm{v}$ realitě každodenní práce školy se pak může snadno stát dalším návdavkem $\mathrm{k}$ již existujícímu „rozporu mezi loajalitou ke školskému systému a (profesním) svědomím“ učitele. Tedy novým intenzivním zdrojem skrytého problému morálního distresu učitelů, o kterém v tomto čísle Pedagogiky píše Jiř̌i Mareš. Nezdar inkluze bude zase připisován učiteli? 